\title{
Od ksiaż̇i ilustrowanej do książki obrazkowej. Rola ilustracji w przekładzie Domowych duchów Dubravki Ugrešić
}

\author{
Abstract \\ From the Illustrated Book to the Picture Book. The Role of Illustrations in the Translation \\ of Kućni duhovi by Dubravka Ugrešić
}

This paper focuses on the illustrations appearing in the Polish edition of the Kućni duhovi by Dubravka Ugrešić. Hardly anyone remembers that this world-famous Croatian writer made her debut as a writer for children (Mali plamen, 1971; Filip i srećica, 1976). Unfortunately, these texts are almost unknown outside of Croatia. Only the collection of stories Kućni duhovi from 1988 has been translated into foreign languages. The author of the Polish translation is Dorota Jovanka Ćirlić, while the graphic design was created by Iwona Chmielewska, one of the most titled and recognizable Polish illustrators in the world. In her works, Chmielewska used many elements evoking socialist Yugoslavia. The Yugoslavian banknotes and coins, logos and labels, posters of musical bands and characters associated with this geographical area appearing in the illustrations were combined with Dutch and North European painting. Thanks to this, the pictures created by Chmielewska not only illustrate the content of the work, but they can also be read as a separate story - a kind of visual biography of Ugrešić, which consists of images from before the break-up of Yugoslavia and life in exile in the Netherlands. In this paper, I show that we are also dealing with a change of the ontological status of the book in the Polish edition of Kućni duhovi. Both the Croatian and Serbian editions are examples of illustrated books where basic communication code is text, while the image is only an illustration of the content. On the other hand, a picture book has been given to Polish readers, in which the text and image play an equal role.

Keywords: children's literature, Dubravka Ugrešić, illustrated book, picture book, Ilona Chmielewska, Yugoslavia, Dutch and North European painting

Słowa kluczowe: literatura dziecięca, Dubravka Ugrešić, książka ilustrowana, książka obrazkowa, Ilona Chmielewska, Jugosławia, malarstwo niderlandzkie i północnoeuropejskie 
Domowe duchy ${ }^{1}$ to dziesiąty w kolejności utwór Dubravki Ugrešić przetłumaczony na język polski i pierwszy adresowany do najmłodszych czytelników. Ta najchętniej wydawana poza granicami rodzimej Chorwacji pisarka w kraju nad Wisłą stała się rozpoznawalna dzięki powieściom Muzeum bezwarunkowej kapitulacji (2002) i Ministerstwo Bólu (2006) oraz zbiorom esejów Kultura kłamstwa $(1998,2006)$ i Czytanie wzbronione (2004), które ukazały się w przekładzie Doroty Jovanki Ćirlić. Dla popularności jej twórczości nie bez znaczenia pozostał również fakt, że powieść Stefcia Ćwiek w szponach życia ${ }^{2}$ (Stefica Cvek u raljama života) z 1980 roku, której tłumaczenie ukazało się w Polsce dopiero w roku 2002, dwukrotnie była wystawiana na deskach teatru. Pierwszej adaptacji, w reżyserii Krystyny Jandy, dokonał w 2005 roku Teatr Polonia, drugiej zaś, w reżyserii Mateusza Przyłęckiego, w 2009 roku, krakowski Teatr Ludowy.

Dubravka Ugrešić zadebiutowała w 1971 roku zbiorem opowiadań dla dzieci Mali plamen ${ }^{3}$. Kolejny jej utwór, Filip i srećica ${ }^{4}$, również przeznaczony był dla najmłodszych odbiorców. Romans pisarki z literaturą dziecięcą zakończył się w 1988 roku, kiedy to ukazał się zbiór Kućni duhovi ${ }^{5}$. Niestety teksty te są poza Chorwacją prawie nieznane. Jedynie ostatni z nich doczekał się tłumaczeń na języki obce. W roku 2010 ukazało się wydanie polskie oraz serbskie ${ }^{6}$, a w 2018 książka została wydana w Bułgarii ${ }^{7}$. Autorką polskiego przekładu jest wspomniana Dorota Jovanka Ćirlić, tłumaczka większości książek chorwackiej pisarki, natomiast szatę graficzną stworzyła wybitna ilustratorka Iwona Chmielewska.

Analizowana w niniejszym szkicu książka stanowi zbiór 27 opowiadań o duchach, które zadomowiły się w jednej z zagrzebskich kamienic. Niektóre z nich żyją z mieszkańcami w symbiozie, jednak w większości przypadków są to chochliki zatruwające życie domowników. Spotykamy tu między innymi Palcożerka (chor. Prstožder) - stworka, który obgryza palce śpiących mieszkańców; Cucha (chor. Knerdo) - psotnika ukrywającego się w koszu z brudną bielizną i wydającego nieprzyjemne zapachy; Gliglusie (chor. Dorseni) - szalone duchy, które uwielbiają łaskotki; Igielniki (chor. Tutumaši) - stworki zjadające igły, szpilki i pinezki; pukające nocami w ściany Stukpuki (chor. Kucači); rozrabiające w łazienkach Mydlańce (chor. Sapunari), które ku rozpaczy właścicieli mieszkań pozostawiają po sobie straszny bałagan, czy Pasibrzuchy (chor. Žderači) - chochliki wykradające jedzenie z kuchni i spiżarni. Przywołane przykłady pokazują, że duchy powołane do życia przez Dubravkę Ugrešić poszczycić się mogą nie tylko oryginalnymi imionami, stanowiącymi dla autorki polskiego przekładu niemałe wyzwanie translatorskie ${ }^{8}$, ale również nietuzinkowym zachowaniem,

1 D. Ugrešić, Domowe duchy, tłum. D.J. Ćirlić, il. I. Chmielewska, Kraków 2010.

D. Ugrešić, Stefcia Ćwiek w szponach życia, tłum. D.J. Ćirlić, Wołowiec 2002.

D. Ugrešić, Mali plamen, Zagreb 1971.

D. Ugrešić, Filip i srécica, Zagreb 1976.

D. Ugrešić, Kućni duhovi, Zagreb 1998.

D. Ugrešić, Kućni duhovi, Beograd 2010.

Д. Угрешич, Домашни духчета, превод Р. Ляпова, София 2018.

8 Kwestię tę omówiłam w wystąpieniu Oswajanie obcości w przekładzie literatury dziecięcej na przykładzie Domowych duchów Dubravki Ugrešić, zaprezentowanym podczas IV Międzynarodowej 
dziwnymi upodobaniami i nawykami oraz wyjątkową aparycją, czym stwarzają szerokie możliwości dla kreatywności twórcy szaty graficznej.

Ilustracje do pierwszego wydania zbioru przygotowała Branka Ćetković, chorwacka malarka i ilustratorka książek dla dzieci, laureatka wielu nagród, między innymi „Grigor Vitez” (1986), wyróżnienia im. Ivany Brlić-Mažuranić (1987) oraz „Selan Gliha” (1988). Z kolei do współpracy przy edycji serbskiej Ugrešić zaprosiła Dušana Petričicia, utytułowanego ilustratora i karykaturzystę, współpracującego z czołowymi serbskimi tygodnikami, takimi jak „NIN” czy „Politika”. Petričić, który przez dziesięć lat mieszkał i tworzył poza granicami Serbii, może się poszczycić międzynarodowym uznaniem. Jego prace ukazywały się na łamach amerykańskich i kanadyjskich czasopism: „The New York Times”, „The Wall Street Journal” czy „Toronto Star”. Ilustrował również książki dla dzieci wielu zagranicznych autorów, takich jak: Simon Shapiro, Mordecai Richler, Sarah Ellis, Tim Wynne-Jones, Aubrey Davis, Margaret Atwood czy Shannon Stewart. Z jednej strony rozpoznawalność i popularność Petričicia, z drugiej zaś zapewne - względy finansowe sprawiły, że wydana w ubiegłym roku bułgarska wersja Domowych duchów ukazała się z ilustracjami jego autorstwa, tymi samymi, które pojawiają się w edycji serbskiej. Zauważyć również można, że zarówno ilustracje Branki Ćetković, jak i Dušana Petričicia przede wszystkim obrazują treść książki. Ich zadaniem jest - zgodnie z definicją Janiny Wiercińskiej - „objaśnienie, uzupełnienie, interpretowanie lub dopowiadanie tekstu, ewokowanie pewnych stanów uczuciowych, wzmagających działanie utworu"9. W obydwu wydaniach szata graficzna porusza odbiorcę, pobudza jego wrażliwość, uruchamia skojarzenia i ,nabiera wagi samodzielnego języka niezależnie od tekstu podejmującego wraz z nim te same problemy" "10, jednak to tekst zachowuje rolę dominującą. Elementy wizualne pełnią jedynie rolę ilustrującą opowiadaną historię i nie modyfikują jej sensu. Ich funkcja sprowadza się przede wszystkim do opisu polegającego na ,bezpośrednim wyjaśnieniu tekstu przez demonstrację wyobrażenia wzrokowego"11 oraz interpretacji, gdyż często stanowią „twórczy komentarz wydobywający istotną treść"12. Na tym tle polskie Domowe duchy znacznie różnią się od wydań południowosłowiańskich.

Iwona Chmielewska, zaproszona przez Ugrešić do współpracy, to jedna z najbardziej utytułowanych ${ }^{13}$ i rozpoznawalnych na świecie współczesnych polskich ilustratorek oraz autorka książek obrazkowych (picture books). Jej utwory są

Konferencji Naukowej z cyklu „Słowiańszczyzna - dawniej i dziś. Język - literatura - kultura”, która odbyła się we Wrocławiu w dniach 4-5.04.2019.

9 J. Wiercińska, Sztuka i ksiażka, Warszawa 1986, s. 37.

10 A. Sędziwy, O ilustracji słów kilka [w:] Współczesna polska sztuka książki. Ilustracje ksiązkowe. Katalog wystawy, Warszawa 1998, s. 25.

11 K. Głombiowski, Książa w procesie komunikacji społecznej, Wrocław-Warszawa-KrakówGdańsk 1980, s. 59.

12 Ibid.

13 Chmielewska jest m.in. dwukrotną laureatką nagrody Bologna Ragazzi Award, tzw. ilustratorskiego Oscara (2011, 2013); nagrody IBBY Książka roku 2011 w kategorii „książka obrazkowa”; nagrody głównej w Konkursie Literatury Dziecięcej im. Haliny Skrobiszewskiej (2011), którego organizatorem jest Muzeum Książki Dziecięcej w Warszawie, oraz nagrody Złote Jabłko na Międzynarodo- 
najczęściej dziełami autorskimi, chociaż - tak jak w przypadku omawianej tu pozycji - w jej dorobku odnaleźć można publikacje powstałe we współpracy z innymi pisarzami ${ }^{14}$. Na bogatą twórczość Chmielewskiej składają się książki obrazkowe nienarracyjne, przypominające zbiory aforyzmów czy refleksji, oraz narracyjne, które - jak podkreśla Marta Baszewska - ,opierają się na zrębach tradycyjnej fabuły czy konwencjonalnych literackich chwytów"15. Utwory Chmielewskiej wymykają się wszelakim klasyfikacjom ${ }^{16}$. Artystka, podobnie zresztą jak Ugrešić w swoich powieściach, chętnie posługuje się zapożyczeniem, kolażem i montażem, zapraszając odbiorców do procesu tworzenia. „W swoich książkach staram się - jak sama podkreśla - ukryć własne ego, właśnie dlatego, żeby każdy odbiorca mógł w nich odnaleźć siebie i mógł powiedzieć «To jest MOJA książka». Chciałabym, żeby czytelnik stał się jej współtwórcą"17.

Książki Iwony Chmielewskiej tworzą swoistego rodzaju łamigłówki, które czytelnik/widz stara się rozwiązać. Układając poszczególne elementy w całość, odbiorca podąża za subtelnie ,podrzuconymi” przez autorkę wskazówkami, kierując się przy tym asocjacjami i konotacjami. Artystka stara się w maksymalny sposób wykorzystać potencjał współczesnej poligrafii oraz edytorstwa. Książki wykonuje ręcznie, wykorzystując różne tworzywa: tekturę, stare tkaniny, wycinki z gazet, książek i zapisów nutowych, papier kolorowy i milimetrowy, kawałki tapet, nici, sznurki, etykiety i opakowania. Często są to materiały zużyte i niepotrzebne, tym samym autorka uprawia - jak podkreślają badacze jej twórczości „artystyczny recykling sentymentalny” ${ }^{18}$. Chmielewska sięga po różne techniki, wprawnie posługuje się ołówkiem, kredkami, akwarelami i nożyczkami. Tworząc kolaże, chętnie operuje figurami i kształtami oraz często wykorzystuje efekt iluzji. Zachęca czytelnika do zabawy z ilustracjami, do tego, by dopełnił je własnymi skojarzeniami. Z wykorzystaniem tych metod powstała również szata graficzna polskiego wydania książki Dubravki Ugrešić.

Przygotowanie ilustracji do Domowych duchów było dla Chmielewskiej zadaniem niełatwym i wymagającym. Zanim przystąpiła do pracy, solidnie się przygotowała i przeczytała - jak sama wspomina - „«dorosłe» książki Ugrešić, poznając z nich zawiłą historię Bałkanów"19. Natomiast o początkach współpracy z chorwacką pisarką artystka pisze:

Kiedy Dubravka Ugrešić zaproponowała mi zilustrowanie książki Domowe duchy, od razu wiedziałam, że musi powstać książka wyjątkowa nie tylko dlatego, że tekst jest inspirujący,

wym Biennale w Bratysławie (2007). Jej książki znalazły się również na liście Białych Kruków 2012 Internationale Jugendbibliothek w Monachium oraz na liście Skarbów Muzeum Książki Dziecięcej.

14 Zob. m.in. K. Miłobędzka, Na wysokiej górze, Poznań 2014; K. Iłłakowiczówna, Czarownica, Poznań 2015; J. Czechowicz, Dopóki niebo nie płacze, Lublin 2016; K. Heekyoung, Maum. Dom duszy, Wrocław 2016.

15 M. Baszewska, Architektura picture booka. Twórczość Iwony Chmielewskiej, „Sztuka Edycji” 2016, nr 2, s. 118 .

16 Zob. ibid.

17 Picture book. Rozmowa z Iwona Chmielewska, rozmawiała E. Kruszyńska, „Polonistyka” 2011, nr 3, s. 61.

18 M. Baszewska, Architektura..., op. cit., s. 119.

19 I. Chmielewska, Od ilustratorki [w:] D. Ugrešić, Domowe duchy, op.cit., s. 60. 
ale również ze względu na osobę autorki, która zmuszona była z przyczyn politycznych opuścić swoją ojczyznę ${ }^{20}$.

Zatem od samego początku u podstaw działań artystycznych Chmielewskiej leżały inspiracje pozaliterackie, przede wszystkim biografia pisarki, która wybrała los apatrydy i otwarcie przyznaje się do jugonostalgii, za co w latach dziewięćdziesiątych XX wieku była w swojej ojczyźnie głośno krytykowana i skazana na ostracyzm. Stworzona przez polską artystkę szata graficzna utworu ma podwójny wymiar. Z jednej strony ilustruje tekst, niekiedy jest owocem jego interpretacji, gdyż dopowiada czy wyjaśnia to, co nie zostało w nim wyrażone w sposób bezpośredni. Z drugiej zaś można ją „czytać” niezależnie, jako odrębną opowieść o losach autorki tekstu oraz kraju, w którym żyła przez ponad czterdzieści lat. Chmielewska tym samym stworzyła rodzaj wizualnej biografii Ugrešić, na którą składają się obrazy sprzed rozpadu Jugosławii oraz życia na emigracji w Holandii. Wprawny czytelnik odnajdzie również twarze osób, które los zetknął z chorwacką pisarką - jest wśród nich tłumaczka tekstu, Dorota Jovanka Ćirlić, oraz sama ilustratorka (zob. ilustracje 1 i 2).

Zagrzebską kamienicę, w której toczą się opisywane przez Ugrešić wydarzenia, Iwona Chmielewska potraktowała jako metaforę Jugosławii, gdzie - jak sama dobitnie podkreśla - „wszyscy żyli razem, szanując swoją różnorodność, odwiedzając się nawzajem i jak bliscy sąsiedzi ze zrozumieniem wysłuchując opowieści o codzienności" ${ }^{21}$. Tworząc ilustracje, artystka wykorzystała między innymi jugosłowiańskie banknoty i monety, kilka logo, etykiety oraz opakowania popularnych wówczas produktów, przede wszystkim artykułów spożywczych i przedmiotów codziennego użytku. Natknąć się możemy między innymi na papierosy marki Filter Jugoslavija, słoik ogórków konserwowych Jadranka, przyprawę do zup i sosów wyprodukowaną przez chorwacką Podravkę, słoweńską pralkę Gorenje czy Yugo - dumę jugosłowiańskiej motoryzacji (zob. ilustracja 3). Ściany poszczególnych mieszkań dekorują: mapa Jugosławii, plakat zespołu Bijelo dugme czy portret Nikoli Tesli. Z kolei na jednej z szafek dostrzec można płytę winylową z nagraniami Ivana Pogorelicia, światowej sławy chorwackiego pianisty, a w telewizorze - sylwetkę popularnego piłkarza Davora Šukera. Użyte przez artystkę reprodukcje oryginalnych grafik (obwolut, etykiet, logotypów) oraz stworzone na ich wzór nowe niosą ze sobą bogaty ładunek informacyjny i jednoznacznie odsyłają do sfery życia codziennego socjalistycznej Jugosławii. Wykorzystanie ich jako ilustracji towarzyszącego tekstu urozmaica go i wzbogaca oraz uruchamia u odbiorcy utworu skojarzenia i skłania do poszukania informacji bardziej szczegółowych. Ilustracje, w których wykorzystane zostały reprodukcje grafik, oddziałują zwłaszcza na czytelników dorosłych, gdyż odsyłają do doświadczeń codzienności w poprzednim systemie politycznym, które są obce dzieciom. Dzięki nim ,finalny obraz jest wypadkową obrazów kształtowanych w dwóch odrębnych układach semantycznych: słowa i wizualizacji”22.

20 Ibid.

21 Ibid.

22 A. Saj, Ilustracja zwykła i niezwykła [w:] Współczesna polska sztuka książki. Ilustracja. Katalog wystawy, Warszawa 2000, s. 23. 
Opowieść Dubravki Ugrešić o niesfornych domowych duchach kończy widniejąca na ostatniej stronie, tuż pod spisem treści, grafika przedstawiająca rozbite jajko. Pomiędzy skorupkami widać również ślady malutkich stóp znikających poza obszarem strony, na której uchwycony został jedynie fragment czerwonej czapki niewielkiego zbiega (ilustracja 4). Czytelnik wie, że najpewniej należała do jednego z Myszołków, dla których Madame Ewian wydziergała na drutach charakterystyczne nakrycia głowy. W ten zabawny sposób Chmielewska nawiązała do grafiki z kultowej już publikacji Leksikon Yu mitologije ${ }^{23}$, przedstawiającej rozbite na dwie części jajo, w którego skorupkach dostrzec można kontury Jugosławii. Jajko pojawiające się na obydwu ilustracjach przywodzi na myśl bośniacką miejscowość Jajce, gdzie w 1943 roku proklamowano socjalistyczną Jugosławię, natomiast rozbite skorupki w symboliczny sposób obrazują rozpad państwa ${ }^{24}$.

Przestrzeń jugonostalgii Chmielewska postanowiła połączyć z malarstwem europejskim, dzięki czemu zamieszczone w książce ilustracje wywołują liczne skojarzenia, zwłaszcza u dorosłych odbiorców. Pojawiają się w nich motywy, postaci oraz przedmioty zapożyczone z obrazów pędzla mistrzów niderlandzkich oraz niemieckich. W ten sposób artystka chciała pokazać - jak sama tłumaczy - ,że ludzie żyjący w różnych miejscach i w różnym czasie mogą mieć podobne twarze, że w swojej codzienności przybierają identyczne pozy"25, i nawiązać jednocześnie do losów chorwackiej pisarki. Pomieszanie odległych czasów i przestrzeni geograficznych oraz obcych sobie kultur prowokuje do zabawy z ilustracjami, zachęca do odszukiwania powiązań i inspiracji oraz odczytywania ukrytych w nich kodów.

Szczególnie inspirujące stały się dla Chmielewskiej płótna Jana Vermeera, holenderskiego malarza tworzącego w połowie XVII wieku, autora scen rodzajowych, mistrzowsko wykorzystującego w swych pracach grę światła. Na kartach Domowych duchów odnajdujemy wiele postaci oraz scen pojawiających się na jego płótnach. Jedno z nich - Dziewczyna czytająca list przy otwartym oknie (olej na płótnie, 1659) - potraktowane zostało jako ozdoba: wykonany ołówkiem rysunek wiszący na ścianie. Jednak znacznie częściej ilustratorka sięga po pojawiające się w pracach artysty postaci w celu sportretowania poszczególnych bohaterów książki Ugrešić. Niekiedy wykorzystuje jedynie pojedyncze części ich ciał, najczęściej twarze oraz ręce. W ten sposób Dziewczyna z perła (olej na płótnie, 1665), jeden z najbardziej znanych obrazów Vermeera, uchodząca - jak podkreślają znawcy - „za Mona Lisę Północy”26, stała się portretem ,zwykle małomównej dziewczynki o bladej twarzy, Inki S., z czwartego piętra"27 (zob. ilustracja 5).

23 Leksikon YU mitologije, ured. I. Adrić, V. Arsenijević, Đ. Matić, Beograd-Zagreb 2004.

24 Motyw rozbitego jajka użyty w kontekście rozpadu Jugosławii pojawia się również w filmie Dušana Makavejeva zatytułowanym WR-tajemnice organizmu. Szerzej na ten temat zob. A. Bošković, Yugonostalgia and Yugoslav Cultural Memory: Lexicon of Yu Mythology, ,Slavic Review” 2013, nr 1, s. 64.

25 I. Chmielewska, op. cit., s. 60-61.

26 K. Menzel, Jan Vermeer i niderlandzkie malarstwo rodzajowe XVII wieku, tłum. T. Kowalewski, Bratislava 2016, s. 7.

27 D. Ugrešić, Domowe duchy, op. cit., s. 18. 
Z kolei Śpiaca dziewczyna (olej na płótnie, 1656-1657) została przez artystkę wykorzystana jako ilustracja przedstawiająca panią Chochelkę, w której domu zamieszkał złośliwy duch Jojśpik, posiadający zdolność usypiania ludzi w najmniej ku temu odpowiednim momencie, na przykład podczas gotowania. Na kolejnych ilustracjach dostrzegamy Mleczarkę nalewajacą mleko (olej na płótnie, 1660), która przeistoczyła się w Jagodę Groch, sąsiadkę z drugiego piętra, oraz Kobietę z dzbanem (olej na płótnie, 1662), użyczającą twarzy pani Klarze, która - jak czytamy - „każdego dnia otwierała okno na swoim drugim piętrze, kładła na parapecie haftowaną poduszeczkę, opierała się na niej i godzinami wpatrywała w ulicę"28. Co ciekawe, w utworze występują aż trzy ilustracje przedstawiające tę bohaterkę. W przypadku pozostałych dwóch polska artystka również wykorzystała kobiece twarze pojawiające się na obrazach Vermeera -Dziewczyne grajacca na gitarze (olej na płótnie, 1672) oraz Dame piszaca list (olej na płótnie, 1665). Kobieta na ilustracjach Chmielewskiej odziana jest w suknię o tej samej żółtej barwie co na płótnach niderlandzkiego mistrza, a jej szyję przyozdabia sznur pereł. Detal ten pojawia się jedynie na pierwszym obrazie (Dziewczyna grająca na gitarze). W przypadku postaci „zapożyczonej” z drugiego malowidła (Dama pisząca list) nie zgadza się również fryzura, ale jest to uwarunkowane treścią utworu. Pani Klara wyłysiała z powodu ducha Pieszczocha, który nawiedził jej dom. W celu zilustrowania emerytowanej nauczycielki Cecylii Rusin Chmielewska posłużyła się obrazem zatytułowanym Głowa dziewczyny, studium (olej na płótnie, 1665-1667). Natomiast zapominalska pani Nieman, która „stale się skarży, że wciąż znikają jej kapcie”29, do złudzenia przypomina postać z płótna Kobieta z waga (olej na płótnie, 1664), z tym że zamiast wagi trzyma $\mathrm{w}$ dłoni zwisające na cienkiej tasiemce damskie bambosze. Częściowo zgadza się również kolorystyka ubioru obydwu postaci oraz białe nakrycie głowy. Inna ilustracja przedstawiająca tę samą bohaterkę nawiązuje z kolei do obrazu zatytułowanego Kobieta $w$ naszyjniku z pereł (olej na płótnie, 1664), co sugeruje ten sam układ rąk obydwu bohaterek stojących przed oknem i spoglądających w dal. Chmielewska na strony Domowych duchów przeniosła również Koronczarkę (olej na płótnie, 1669-1670), która została wykorzystana w celu sportretowania krawcowej Krystyny Tasiemki podczas pracy. Tutaj również zachowane zostały oryginalna kolorystyka i fason stroju (zob. ilustracja 6).

Z kolei Miłorzęb Kalkulak, ,poważny człowiek interesu z trzeciego piętra" ${ }^{30}$, sportretowany został przy wykorzystaniu dwóch malowideł. Pierwsze z nich nosi tytuł Geograf (olej na płótnie, 1669), drugie zaś to Astronom (olej na płótnie, 1668). Postać na ilustracjach uchwycona została w tych samych pozach co na obrazach. Odziana jest również w podobny niebieski płaszcz czy szlafrok z charakterystycznym czerwonym lampasem. Zauważyć można również, że na jednej z ilustracji została odtworzona scena uwieczniona przez holenderskiego mistrza na płótnie zatytułowanym List miłosny (olej na płótnie, 1669-1670). Widać na nim dwie kobiety: damę grającą na gitarze oraz służącą, która przekazuje swojej

$\begin{array}{ll}28 & \text { Ibid., s. } 36 . \\ 29 & \text { Ibid., s. } 33 . \\ 30 & \text { Ibid., s. } 47 .\end{array}$ 
pani tytułowy list. Ta scenka rodzajowa został naszkicowana przez Chmielewską w celu zilustrowania relacji między dwiema sąsiadkami. Z podobnym zabiegiem mamy do czynienia w przypadku jednego z najbardziej charakterystycznych płócien Vermeera, pod tytułem Kuplerka (olej na płótnie, 1656), znanego również jako U stręczycielki. Scena przedstawiona na obrazie rozgrywa się w ciemnym pomieszczeniu domu rozpusty. Na pierwszym planie widzimy wielobarwny, bogato zdobiony dywan leżący na stole, za którym siedzą cztery postaci ukazane od pasa w górę. Pierwsza z prawej, młoda dziewczyna o zaróżowionych policzkach, w żółtej sukni i białym nakryciu głowy, to prostytutka. Kobieta otwiera dłoń, aby przyjąć zapłatę od obejmującego ją mężczyzny w kapeluszu. Za nim stoi i zerka z zadowoleniem zza ramienia tytułowa stręczycielka. Jest to starsza kobieta ubrana na czarno, której głowę zakrywa chusta w tym samym kolorze. Z lewej strony siedzi mężczyzna, który wznosi w górę szklankę z winem i jako jedyny patrzy na widza. Postać ta jest przez znawców uważana za autoportret Vermeera. Ta sama scena pojawia się na ilustracji Chmielewskiej, z tym że rozgrywa się w mieszkaniu sąsiadki Fontasiewicz, które - jak podkreśla narratorka - ,zawsze jest pełne gości" 31 . Za stołem nakrytym kraciastym obrusem siedzą cztery osoby, te same, które widzimy na obrazie holenderskiego artysty. Nieznacznie różnią się od pierwowzorów - mężczyźni pozbawieni zostali charakterystycznego dla epoki ubioru, długich włosów oraz oryginalnych kapeluszy. Głowę młodej kobiety zamiast welonu zdobią długie blond włosy. Niezmieniona pozostała natomiast postać stręczycielki, która z wyrazem zadowolenia na twarzy spogląda na panią Fontasiewicz i tulącego ją sąsiada. Figura mężczyzny usytuowana po lewej stronie stanowi - podobnie jak na pierwowzorze - jedyny łącznik z widzem (zob. ilustracja 7).

Iwona Chmielewska w podobny sposób wykorzystała postaci, które pojawiają się na obrazach Jana van Eycka, przedstawiciela piętnastowiecznego realizmu niderlandzkiego. Na jej ilustracjach dostrzec można między innymi twarz Giovanniego Arnolfiniego, którego artysta sportretował około 1435 roku. Kupiec włoski z Lukki pojawia się na jeszcze jednym malowidle artysty, zatytułowanym Portret matżonków Arnolfinich (olej na desce, 1434), przedstawiającym ceremonię przysięgi małżeńskiej. Ta sama scena została odtworzona przez polską ilustratorkę. Jej bohaterowie, Pucek Kajzerka oraz jego wybranka serca, wykonują te same gesty: trzymają się za lewe ręce, prawa ręka mężczyzny wzniesiona jest do góry w geście przysięgi, natomiast ręka kobiety spoczywa na brzuchu (zob. ilustracja 8). Na piętnastowiecznym malowidle między małżonkami dostrzec można niewielkich rozmiarów ciemnego, kudłatego psa, który symbolizuje wierność małżeńską. Nie towarzyszy on natomiast bohaterom Ugrešić, którzy formalnie nie byli małżeństwem. Zwierzę pojawia się jednak na innej ilustracji tego samego opowiadania, przywodząc na myśl przywiązanie, oddanie, dom i rodzinę, która - sądząc po sporym brzuchu kobiety - wkrótce się powiększy.

Pierwowzorem rysunku przedstawiającego panią Widziawską, której dom nawiedziły Paskudy, stał się portret żony artysty - Portret Margarety van Eyck

31 Ibid., s. 31. 
(olej na desce, 1439). Z kolei twarzy jej małżonkowi użyczył najprawdopodobniej sam mistrz. Ilustratorka zainspirowała się Portretem mężczyzny w turbanie (olej na desce, 1433), który przez badaczy twórczości van Eycka uważany jest za jego autoportret. W innym miejscu artystka posłużyła się postacią Ewy uwiecznionej na Oltarzu Gandawskim, do którego malowidła stworzył Jan van Eyck wspólnie z bratem Hubertem. Bohaterka Chmielewskiej zamiast jabłka trzyma w ręku jajko, które - ukryte przez duszka Huncwota - znalazła w szafie między ubraniami. Z kolei na innej ilustracji sąsiadka Kokosianka uchwycona została w pozie śpiewającego anioła, przedstawionego również na wspomnianym ołtarzu. Kolejną postacią „skradzioną” przez ilustratorkę z obrazów holenderskiego mistrza jest Joris van der Paele, pojawiający się na malowidle zatytułowanym Madonna kanonika Jorisa van der Paele (olej na desce, 1436). Fundator obrazu użyczył twarzy Kajtkowi Bączce.

Iwona Chmielewska zainspirowała się również pracami Quentina Matsysa. Pierwowzór małżeństwa Puchaczy odnajdujemy na obrazie pod tytułem Bankier $z$ żona (olej na desce, 1514). Chociaż ilustratorka odziała postaci we współczesne stroje i pozbawiła je charakterystycznych dla epoki nakryć głowy, to uchwycone zostały w tych samych pozach, w których zamarły na obrazie niderlandzkiego mistrza. W wypukłym lustrze znajdującym się na pierwszym planie obrazu odbija się twarz czytającego człowieka. Zdaniem niektórych badaczy jest to autor dzieła. Identyczne lustro odnajdujemy także na ilustracji Chmielewskiej. Uchwycona w nim podobizna różni się jednak od postaci namalowanej przez Matsysa. Najpewniej w zwierciadle ukazane zostało odbicie chytrego ducha Suwaka, który nawiedził mieszkanie rodziny Puchacz (zob. ilustracja 9).

Inspiracji ilustracji przedstawiającej hydraulika odwiedzającego mieszkanie jednego z bohaterów zbioru Ugrešić doszukać się można z kolei w malowidle Hieronima Boscha zatytułowanym Szarlatan (olej na desce, 1475-1480) (2) $^{32}$ Trzymana wysoko w dwóch palcach kulka została przez Chmielewską zastąpiona gumową uszczelką. Drugi bohater widoczny na ilustracji z tym samym niedowierzaniem co postać na obrazie holenderskiego artysty wpatruje się w akcesoria rozłożone na stole, za pomocą których za chwilę dokona się magiczny eksperyment i niemożliwe stanie się możliwym - kran zostanie naprawiony. Zauważyć można również, że Król Henryk VIII uwieczniony przez niemieckiego malarza Hansa Holbeina Młodszego ${ }^{33}$ użyczył twarzy sąsiadowi Monciakowi, którego mieszkanie nawiedził duch Palcożerek. Natomiast Oswold Krel (Portret Oswolda Krela, olej na desce lipowej, 1499) sportretowany przez Albrechta Dürera, jednego z najwybitniejszych artystów niemieckiego renesansu, stał się Józefem

32 Oryginał obrazu zaginął. Zachowała się kopia, która znajduje się w zbiorach Muzeum Miejskiego Saint-Germain-en-Laye. Zachował się również szkic obrazu, który znajduje się w Luwrze. Zob. W. Fraenger, Hieronim Bosch, tłum. B. Ostrowska, Warszawa 1999, s. 442.

33 Ów portret stanowił część fresku powstałego w latach 1536-1537 w pałacu Whitehall. Oryginał uległ zniszczeniu w wyniku pożaru w 1698 roku. Jednak popularność obrazu zaowocowała licznymi jego kopiami, których zleceniodawcą był najprawdopodobniej sam król. Jedna z nich, która powstała w latach 40. XVI wieku (olej na desce dębowej), znajduje się w zbiorach Muzeum Narodowego w Warszawie. 
Gajdkiem z drugiego piętra. Podobny los spotkał Hieronima Holzschuhera, którego portret (Portret Hieronima Holzschuhera, olej na desce lipowej, 1526) został wykorzystany do zaprezentowania postaci Błażeja Mątka. Z kolei inspiracją dla ilustracji przedstawiającej Jana Stójwilczka, który „dostał ataku niepowstrzymanego śmiechu, wskutek czego pękło mu żebro"34, stały się najprawdopodobniej obrazy autorstwa Lucasa Cranacha Starszego - Salome z głowa św. Jana Chrzciciela (olej na desce, 1526), Judyta z głowa Holofernesa (olej na desce, 1530) oraz Uczta u Heroda (olej na desce, 1533).

Wykorzystanie dzieł malarskich jako ilustracji w utworach literackich nie jest zjawiskiem nowym. Coraz częściej sięgają po nie również ilustratorzy książek dla najmłodszych. Ilustracja staje się wówczas pierwszą formą obcowania dziecka ze sztuką i jest - jak podkreśla Elżbieta Kruszyńska - „wstępem do wychowania ku sztuce"35. W podobnym tonie wypowiada się również Hanna Diduszko, która słusznie zauważa, że „najłatwiej dostępnym miejscem, w którym dziecko może obcować ze sztuką, ciągle jednak pozostaje zacisze domowe. Wystarczy bowiem sięgnąć po książkę, by znaleźć się nie tylko w kręgu sztuki słowa, ale Sztuki w ogóle" "36. Z kolei Joanna Bielska-Krawczyk dodaje, że ,ilustracja, stanowiąc efekt spotkania pisarza $\mathrm{z}$ malarzem, słowa z obrazem, jednocześnie łączy ze sobą w jedną całość motywy zaczerpnięte z przebogatego kalejdoskopu dziedzictwa kulturowego"37. Przytoczone wyżej wypowiedzi w najpełniejszy sposób oddają charakter ilustracji stworzonych przez Iwonę Chmielewską do zbioru opowiadań Dubravki Ugrešić. Z jednej strony stanowią one konkretyzację słów obecnych w utworze, z drugiej zaś odsyłają do przestrzeni pozaksiążkowej. Zachęcają czytelnika do podjęcia wyzwania i odszukania pierwowzorów. Bawią i uczą, są przy tym autentycznym produktem sztuki. Książka staje się dzięki nim swego rodzaju muzeum czy galerią obrazów, medium enkulturacji, zwłaszcza edukacji artystycznej i wizualnej, co nabiera szczególnego znaczenia w dobie społeczeństwa medialnego ${ }^{38}$. Ilustracje Chmielewskiej na zupełnie innych zasadach ustanawiają relacje między tekstem i obrazem. Nie są zależne od treści utworu, korespondują z nią i prowadzą dialog. Często stanowią dla tekstu konkurencję oraz potrafią go zdominować, tym samym podkreślają swoją ,nie tylko partnerską, ale i wyzwoloną rolę w korespondencji literacko-plastycznej"39. Chmielewska walczy z obiegową opinią, że obraz jest łatwiejszy w odbiorze, bo natychmiast oddziałuje na odbiorcę. Jej ilustracje są metaforyczne, odwołują się do symboliki oraz często

34 D. Ugrešić, Domowe duchy, op.cit., s. 12.

35 E. Kruszyńska, Książka obrazkowa i jej rola w rozwoju dzieci-wprowadzenie w problematykę, „Warmińsko-Mazurski Kwartalnik Naukowy. Nauki Społeczne”2012, nr 3, s. 186.

36 H. Diduszko, Pełniej odczuwać, głębiej rozumieć (o relacji: dziecko - sztuka, wychowaniu estetycznym i ksiażce), „Ryms” 2009, nr 5, s. 2.

37 J. Bielska-Krawczyk, Ilustracja-kulturowa przestrzeń spotkania literatury i malarstwa. Kilka słów o działalności ilustratorskiej Jana Lebensteina, „Roczniki Kulturoznawcze” 2010, nr 1, s. 249.

38 Szerzej na ten temat zob. M. Centner-Guz, Wartościowanie wybranych rozwiazań ilustratorskich $w$ ksiązkach dla dzieci przez studentów wczesnej edukacji, ,Lubelski Rocznik Pedagogiczny” 2018, t. XXXVII, z. 1.

39 I. Puchalska, O pożytkach ilustracji literackiej [w:] Archipelag porównań. Szkice komparatystyczne, red. M. Cieśla-Korytowska, Kraków 2007, s. 198. 
wymagają szerokich kompetencji kulturowych. Ich adresatem jest nie tylko dziecko, ale również dorosły, który odczytywać je będzie w odmienny sposób. „Staram się zawsze tak budować [...] książki, żeby były książkami dla ludzi, a nie książkami dla dzieci" ${ }^{40}$ - podkreśla artystka. Idealny model odbioru polskiego przekładu Domowych duchów zakłada zatem obecność opiekuna, który objaśni dziecku świat ukazany w obrazach. Co więcej, jest to książka, która zaprasza czytelnika do zaangażowanego odbioru oraz pozwala podczas każdej kolejnej lektury odkrywać nowe treści.

Ilustracje Iwony Chmielewskiej i tekst Dubravki Ugrešić uzupełniają się nawzajem, a jednocześnie prowadzą niezależne od siebie narracje. Jest to sytuacja niespotykana w przypadku wcześniejszych wydań utworu. Zarówno edycja chorwacka, jak i serbska stanowią przykłady książek ilustrowanych, których podstawowym kodem komunikacji jest tekst, zaś obraz stanowi jedynie ilustrację treści. Rysunki autorstwa Branki Ćetković, kierowane raczej - sądząc po formie, kolorystyce i zinfantylizowanym charakterze szaty graficznej - do młodszych czytelników, niezdolnych do samodzielnej lektury, oraz Dušana Petričicia, adresowane do nieco starszych odbiorców, stanowią dopełnienie tekstu oraz jego reartykulację, są ,prze-pisaniem na inne znaki, ewokującym te same znaczenia, ale innymi sposobami"41. Obrazy w nich zawarte - zgodnie z typologią zaproponowaną przez Sewerynę Wysłouch - konkretyzują przedmioty przedstawione w dziele literackim, dokonując jednocześnie przekładu intersemiotycznego, gdyż stanowią plastyczny ekwiwalent sensów kodowanych przez dzieło literackie ${ }^{42}$. W przypadku polskiego wydania mamy do czynienia ze zmianą statusu ontologicznego książki. Do rąk czytelników trafił nie tyle utwór ilustrowany, ile książka o znamionach picture booka ${ }^{43}$.

Książka obrazkowa (picture book) - czyli taka, w której tekst i obraz pełnią rolę równorzędną, a niekiedy ten drugi dominującą ${ }^{44}$ - mimo że poszczycić się może długą tradycją, nadal postrzegana jest w Polsce jako zjawisko stosunkowo nowe i wciąż się rozwijające. Jak podkreśla Magdalena Sikorska:

40 Ksiązki dla ludzi, a nie dla dzieci - wywiad z Iwona Chmielewska, rozmawiała A. Sikorska-Celejewska, tekst dostępny on-line: http://qlturka.pl/2015/12/07/ksiazki-dla-ludzi-a-nie-dla-dzieci-wywiad-z-iwona-chmielewska/ (dostęp: 20.03.2019).

${ }^{41}$ B. Kaniewska, O ważności obrazków, czyli ilustracja w ksiażce dziecięcej [w:] Literatura $w$ kregu sztuki. Tematy - konteksty - medialne transformacje, red. S. Wysłouch, B. Przymuszała, Poznań 2016, s. 157.

42 Zob. S. Wysłouch, Literatura a sztuki wizualne, Warszawa 1994, s. 100.

${ }_{43} \mathrm{~W}$ publikacjach poświęconych temu zjawisku panuje chaos terminologiczny. Stosowane są m.in. takie określenia, jak: picture book, picturebook, picture-book, książka obrazkowa, książka obrazowa, książka ikonolingwistyczna, książka ikonotekstowa, słowoobraz czy tekstoobraz. Zob. M. Baszewska, Architektura..., s. 116.

44 Rozbieżności w postrzeganiu przez badaczy książki obrazkowej uwarunkowane są najczęściej próbą precyzyjnego określenia związku między tekstem a obrazem. Beata Mazepa-Domagała wyróżnia trzy rodzaje relacji między tekstem a ilustracją: 1) ilustracja przedstawia to, co w tekście nie zostało wyrażone; 2) grafika ilustruje treści zawarte w tekście; 3) ilustracja wnosi własne wartości, ale to tekst posiada dominującą rolę w książce. Zob. B. Mazepa-Domagała, Upodobania obrazowe dzieci w wieku przedczytelniczym w zakresie ilustracji ksiażkowej, Katowice 2011, s. 81. 
Picture booki $[\ldots]$ mają ponad sto lat, jednak nadal pod pewnymi względami pozostają gatunkami nowymi, [...] pojawiły się i zaczęły rozwijać w czasach, w których wiara w możliwość stworzenia jedynej i prostej definicji gwałtownie się uszczupliła. [...] Próba precyzyjnego zdefiniowania [...] picture booka z góry skazana jest na daleko idące uproszczenia, a przez to w ostatecznym rozrachunku na niepowodzenie ${ }^{45}$.

Z całą pewnością nazwa nie oddaje charakteru tego typu publikacji, a występujące w niej zdrobnienie - ,obrazek” - prowadzi do infantylizacji całego gatunku. „Problem polega na tym - zauważa Małgorzata Cackowska - że w naszej kulturze wszelkiej twórczości dla dzieci odejmuje się znaczenie ważności poprzez taką,

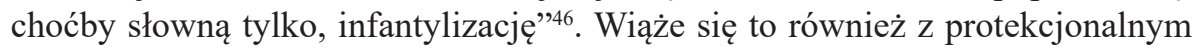
podejściem literaturoznawców i historyków sztuki do tego zjawiska ${ }^{47}$. Tym samym docieramy do kolejnego, nierozstrzygalnego zresztą, problemu - kto powinien zajmować się badaniem tego fenomenu: czy wspomniani wyżej badacze, czy może kulturoznawcy lub pedagodzy? Jak pokazują coraz liczniejsze w ostatnim czasie publikacje, książka obrazkowa stwarza wiele możliwości badawczych ${ }^{48}$ i rzuca nowe światło chociażby na problematykę przekładu literatury dziecięcej.

Patrząc na książkę jako całość, w której tekst i obraz pełnią równorzędną rolę, przyznać trzeba, że polskie wydanie Domowych duchów Dubravki Ugrešić to pozycja zupełnie inna niż oryginał. Odbiorca otrzymuje coś więcej niż rozrywkę. Książka ta pobudza wyobraźnię i ciekawość, wprowadza w świat sztuki, system znaków i symboli kultury oraz poszerza płaszczyznę percepcji i odczuwania rzeczywistości. Przeznaczona jest do czytania i/lub oglądania, a jak zaznacza Hanna Diduszko: ,jeżeli zależy nam, by dziecko stało się naprawdę dobrym, to jest wrażliwym, a później świadomym odbiorcą, powinniśmy mu jak najczęściej towarzyszyć: czytać książkę i oglądać ją razem z nim"49.

\section{Bibliografia}

Baszewska M., Architektura picture booka. Twórczość Iwony Chmielewskiej, „Sztuka Edycji” 2016, nr 2.

Baszewska M., Odkrywanie $i$ detabuizowanie ukrytego $w$ picture bookach Iwony Chmielewskiej [w:] Pongo, t. VIII: Ukryte w kulturze, red. R. Chymkowski, A. Koprowicz, Katowice-Warszawa 2017.

Baszewska M., Picture booki Iwony Chmielewskiej jako medium otwierajace na Innego, „Toruńskie Studia Bibliologiczne” 2016, nr 2 (17).

45 M. Sikorska, Picturebooki i komiksy: koń jaki jest, każdy widzi?, „Zeszyty Komiksowe” 2014, nr 17, s. 14 .

46 M. Cackowska, Czym jest ksiażka obrazkowa?, „Ryms” 2009, nr 5, s. 5.

47 Zob. P. Łapiński, Przekład towarzyszacy. O pozycji tlumacza w świecie literatury obrazkowej dla najmłodszych, „Przekładaniec” 2017, nr 34, s. 72.

48 Zob. m.in. prace Magdaleny Baszewskiej: Picture booki Iwony Chmielewskiej jako medium otwierające na Innego, „Toruńskie Studia Bibliologiczne” 2016, nr 2 (17); Odkrywanie i detabuizowanie ukrytego w picture bookach Iwony Chmielewskiej [w:] Pongo, t. VIII: Ukryte w kulturze, red. R. Chymkowski, A. Koprowicz, Katowice-Warszawa 2017.

49 H. Diduszko, op. cit., s. 4. 
Bielska-Krawczyk J., Ilustracja - kulturowa przestrzeń spotkania literatury i malarstwa. Kilka stów o twórczości ilustratorskiej Jana Lebensteina, „Roczniki Kulturoznawcze" 2010, nr 1.

Bošković A., Yugonostalgia and Yugoslav Cultural Memory: Lexicon of Yu Mythology, ,Slavic Review” 2013, nr 1.

Cackowska M., Czym jest ksiązka obrazkowa?, „Ryms” 2009, nr 5.

Centner-Guz M., Wartościowanie wybranych rozwiąań ilustratorskich w książkach dla dzieci przez studentów wczesnej edukacji, „Lubelski Rocznik Pedagogiczny” 2018, t. XXXVII, z. 1.

Chmielewska I., Od ilustratorki [w:] D. Ugrešić, Domowe duchy, tłum. D.J. Ćirlić, Kraków 2010.

Diduszko H., Petniej odczuwać, głębiej rozumieć (o relacji: dziecko - sztuka, wychowaniu estetycznym i ksiażce), „Ryms” 2009, nr 5.

Fraenger W., Hieronim Bosch, tłum. B. Ostrowska, Warszawa 1999.

Głombiowski K., Książka w procesie komunikacji społecznej, Wrocław-WarszawaKraków-Gdańsk 1980.

Kaniewska B., O ważności obrazków, czyli ilustracja w książce dziecięcej [w:] Literatura w kregu sztuki. Tematy - konteksty - medialne transformacje, red. S. Wysłouch, B. Przymuszała, Poznań 2016.

Kruszyńska E., Książa obrazkowa i jej rola w rozwoju dzieci - wprowadzenie w problematyke, ,Warmińsko-Mazurski Kwartalnik Naukowy. Nauki Społeczne” 2012, nr 3.

Książki dla ludzi, a nie dla dzieci - wywiad z Iwona Chmielewska, rozmawiała A. Sikorska-Celejewska, http://qlturka.pl/2015/12/07/ksiazki-dla-ludzi-a-nie-dla-dzieci-wywiad-z-iwona-chmielewska/ (dostęp: 20.03.2019).

Leksikon YU mitologije, ured. I. Adrić, V. Arsenijević, Đ. Matić, Beograd-Zagreb 2004.

Łapiński P., Przekład towarzyszacy. O pozycji ttumacza w świecie literatury obrazkowej dla najmłodszych, „Przekładaniec” 2017, nr 34.

Mazepa-Domagała B., Upodobania obrazowe dzieci $w$ wieku przedczytelniczym w zakresie ilustracji książkowej, Katowice 2011.

Menzel K., Jan Vermeer $i$ niderlandzkie malarstwo rodzajowe XVII wieku, thum. T. Kowalewski, Bratislava 2016.

Picture book. Rozmowa z Iwona Chmielewska, rozmawiała E. Kruszyńska, „Polonistyka" 2011, nr 3.

Puchalska I., O pożytkach ilustracji literackiej [w:] Archipelag porównań. Szkice komparatystyczne, red. M. Cieśla-Korytowska, Kraków 2007.

Saj A., Ilustracja zwykła i niezwykła [w:] Współczesna polska sztuka książki. Ilustracja. Katalog wystawy, Warszawa 2000.

Sędziwy A., O ilustracji słów kilka [w:] Współczesna polska sztuka książki. Ilustracje ksiażkowe. Katalog wystawy, Warszawa 1998.

Sikorska M., Picturebooki i komiksy: koń jaki jest, każdy widzi?, „Zeszyty Komiksowe" 2014, nr 17.

Ugrešić D., Domowe duchy, tłum. D.J. Ćirlić, Kraków 2010.

Угрешич Д., Домашни духчета, превод Р. Ляпова, София 2018.

Ugrešić D., Filip i srećica, Zagreb 1976.

Ugrešić D., Kućni duhovi, Beograd 2010. 
Ugrešić D., Kućni duhovi, Zagreb 1998.

Ugrešić D., Mali plamen, Zagreb 1971.

Ugrešić D., Stefcia Ćwiek w szponach życia, thum. D.J. Ćirlić, Wołowiec 2002.

Wiercińska J., Sztuka i ksiązka, Warszawa 1986.

Wysłouch S., Literatura a sztuki wizualne, Warszawa 1994. 


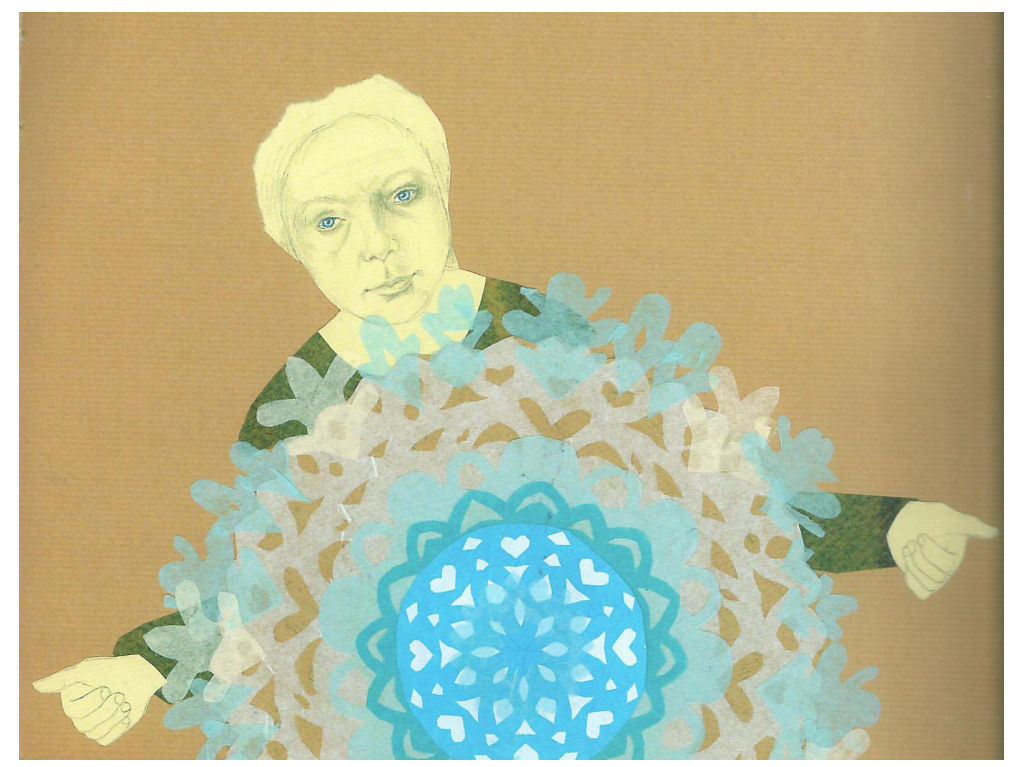

Ilustracja 1

Iwona Chmielewska

Źródło: D. Ugrešić, Domowe duchy, s. 11

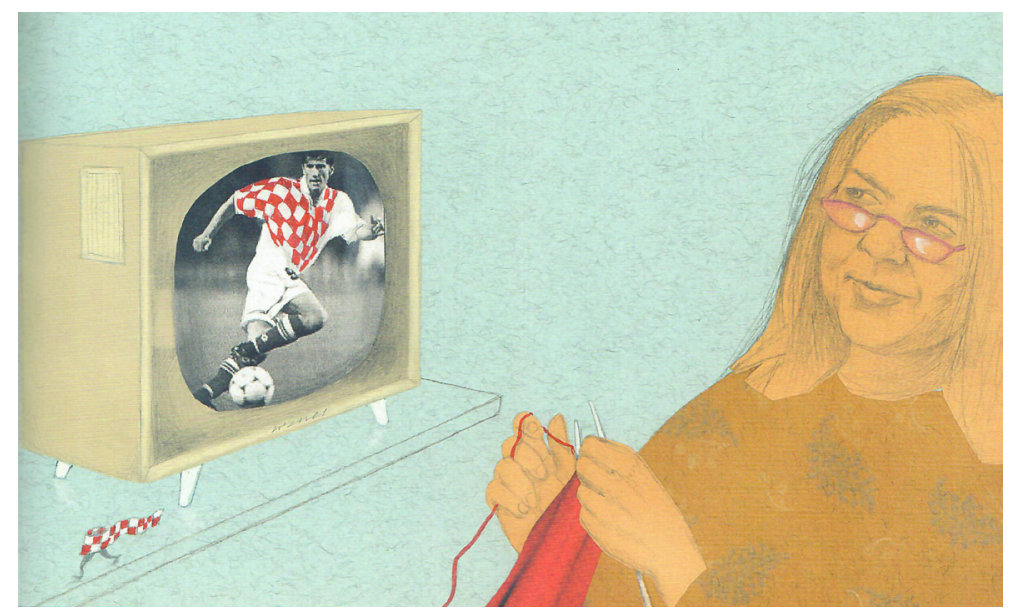

Ilustracja 2

Dorota Jovanka Ćirlić

Źródło: D. Ugrešić, Domowe duchy, s. 29 


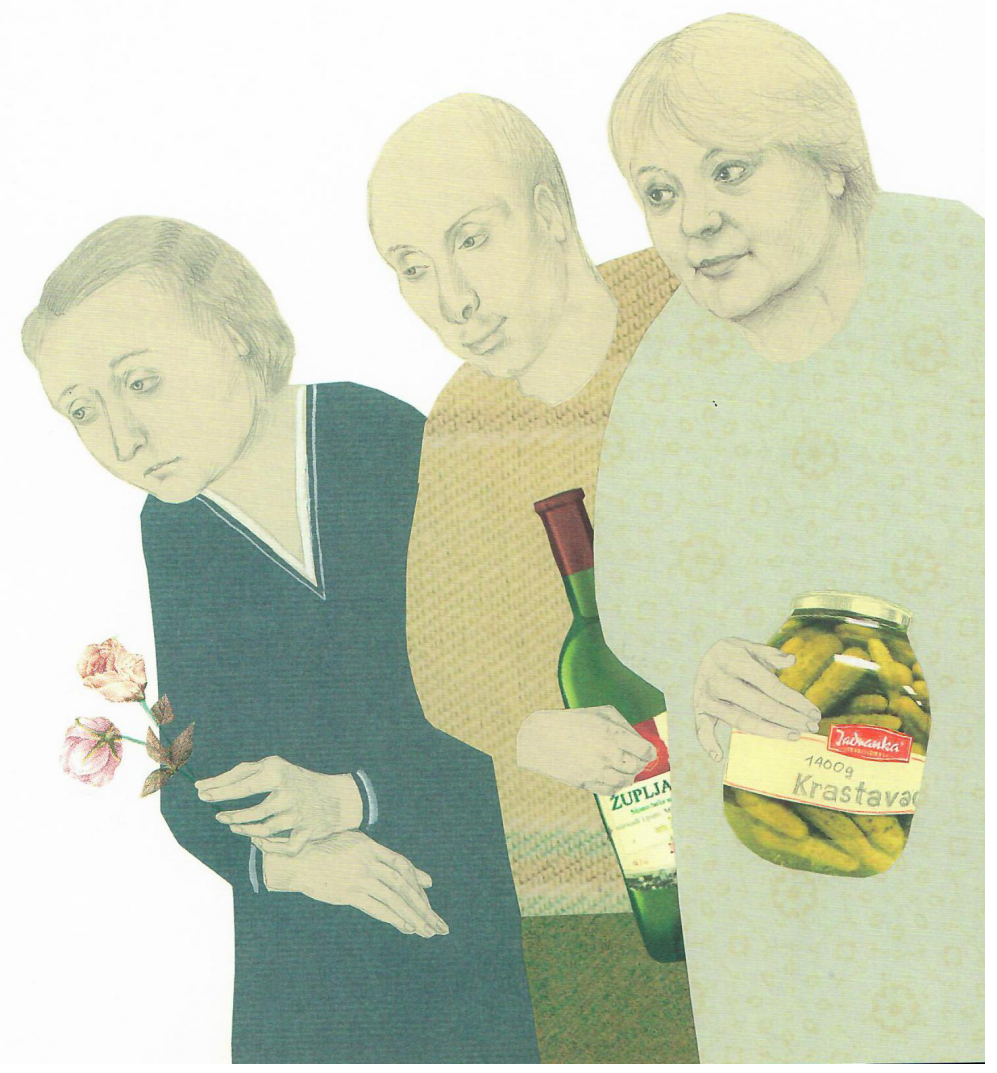

Ilustracja 3

Źródło: D. Ugrešić, Domowe duchy, s. 13

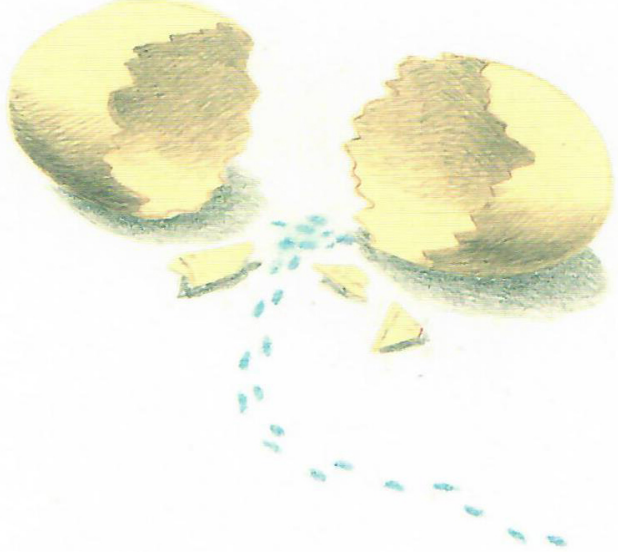

Ilustracja 4

Źródło: D. Ugrešić, Domowe duchy, s. 63 


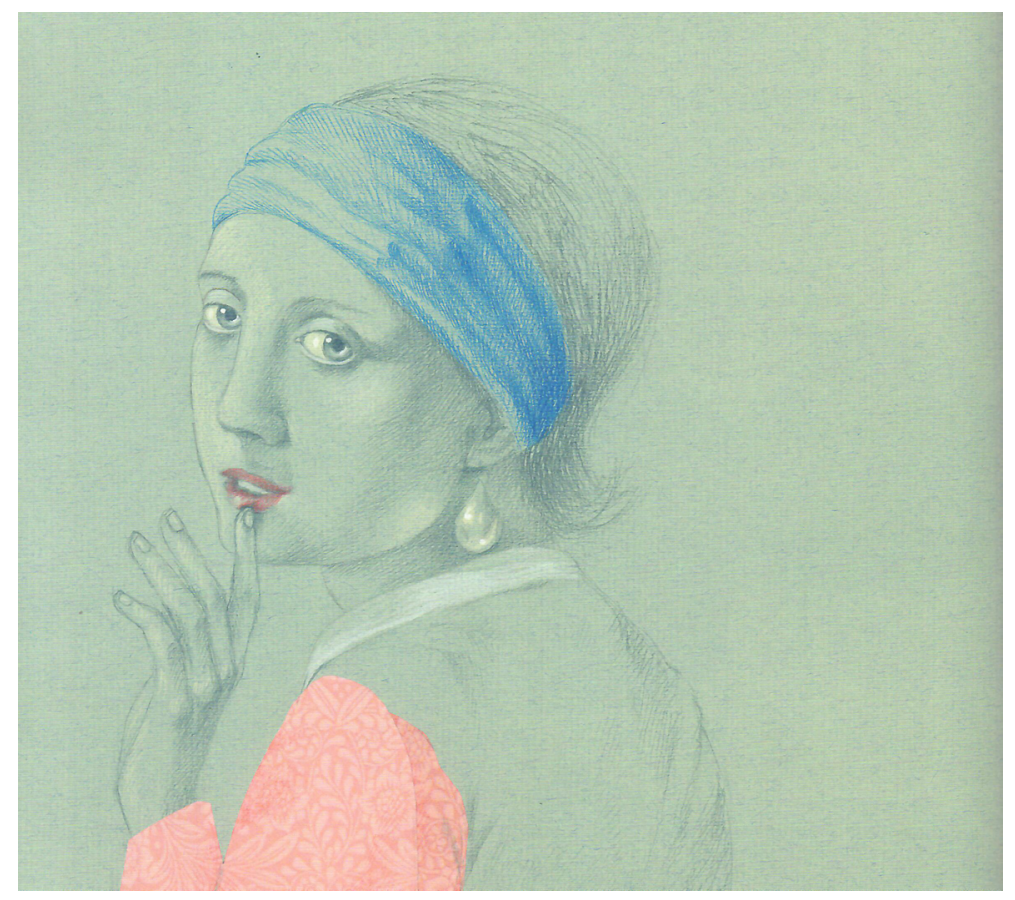

Ilustracja 5

Źródło: D. Ugrešić, Domowe duchy, s. 18

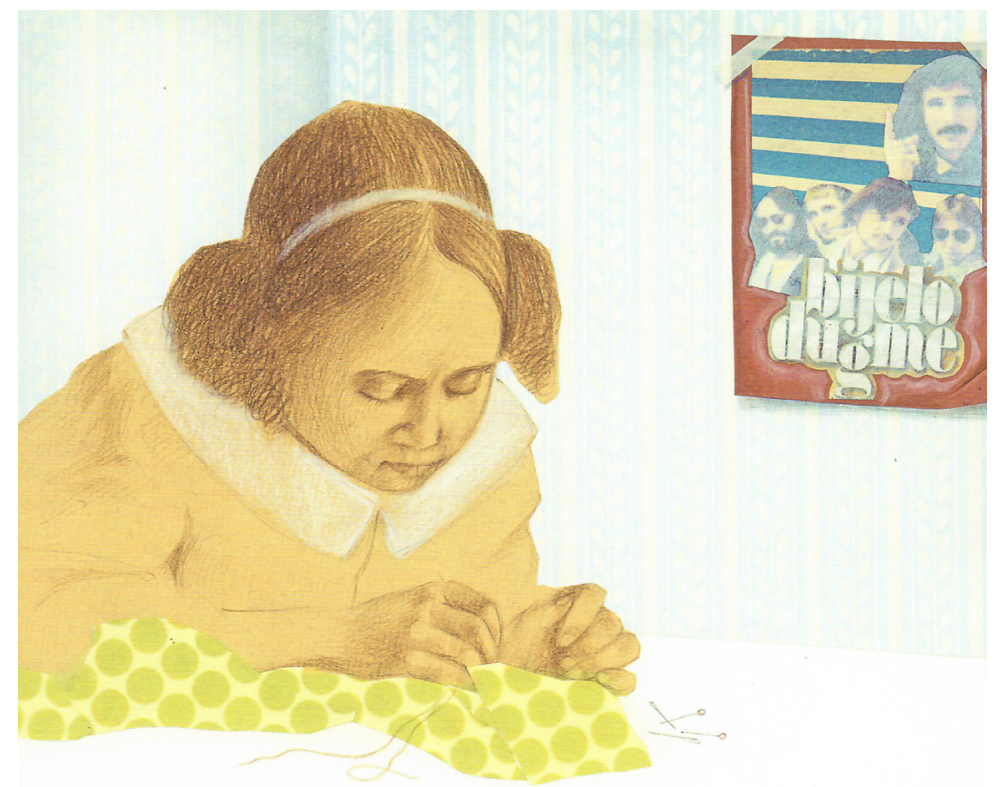

Ilustracja 6

Źródło: D. Ugrešić, Domowe duchy, s. 54 


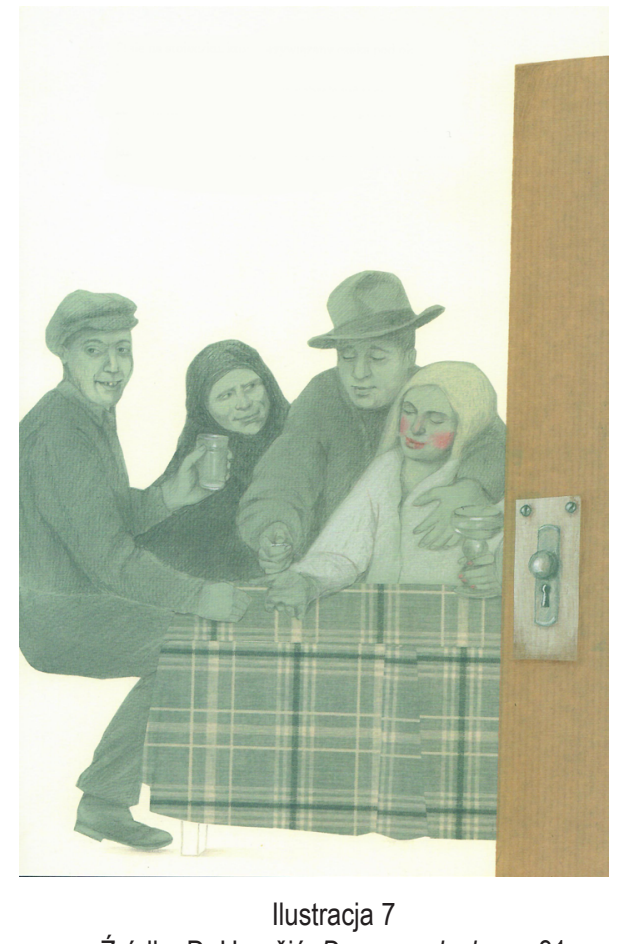

Źródło: D. Ugrešić, Domowe duchy, s. 31

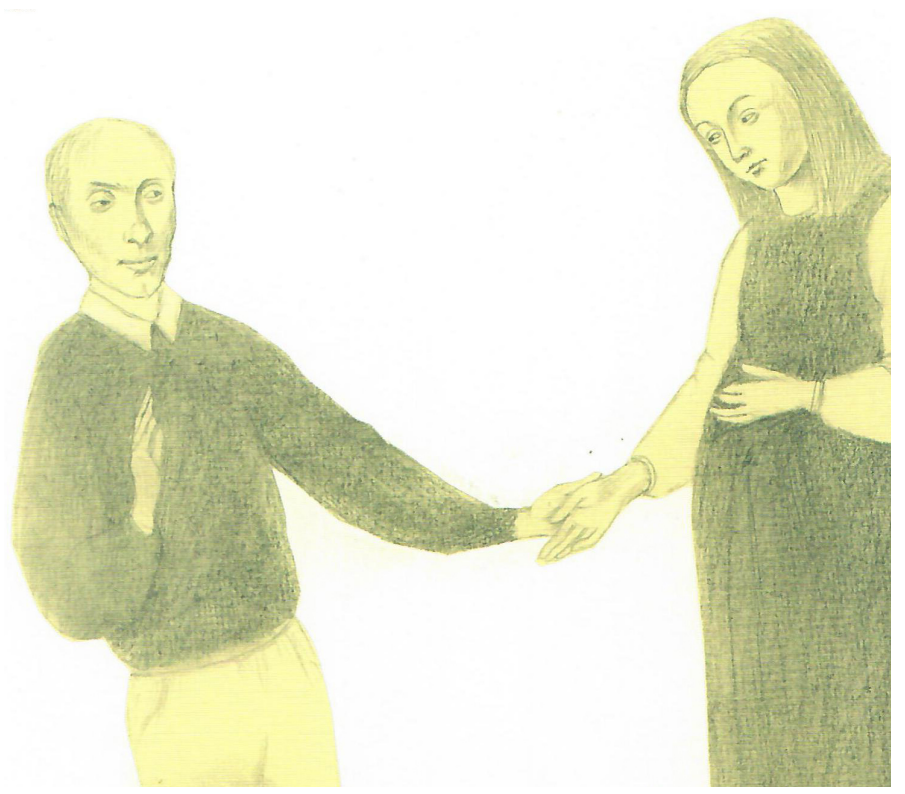

Ilustracja 8

Źródło: D. Ugrešić, Domowe duchy, s. 15 


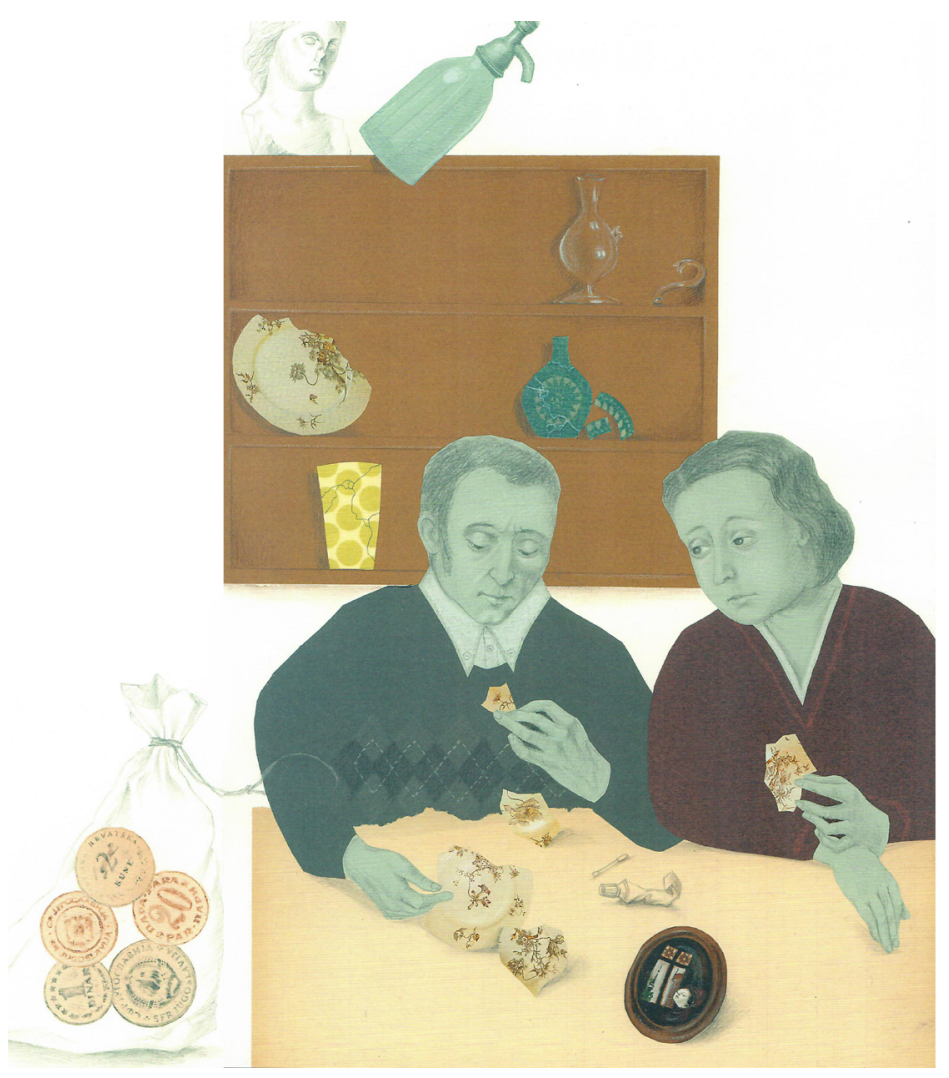

Ilustracja 9

Źródło: D. Ugrešić, Domowe duchy, s. 41 